\title{
Determinants of unemployment duration for young men and women in Tunisia
}

\author{
Farouk Kriaa *, Mohamed Bouhari *D, Yamina Mathlouthi ** \\ * Faculty of Economics and Management of Tunis, University of Tunis Al Manar, Tunisia \\ E-mail: faroukkriaa@yahoo.fr; mohabouhtn@yahoo.com \\ ** Higher School of Communication of Tunis, Tunisia \\ E-mail:yamina.mathlouthi@supcom.tn
}

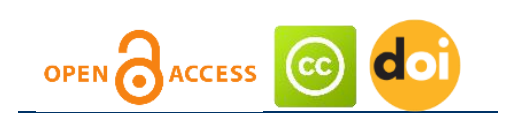

Article history:

Received: July 07, 2020

1st Revision: August 18, 2020

Accepted: October 31, 2020

\section{JEL classification: \\ E24 \\ J64 \\ J01}

DOI:

10.14254/jems.2020.5-2.5

\begin{abstract}
This paper investigates the impact of individual characteristics (gender, age, education level, and marital status) and regional influences on unemployment duration of young in Tunisia using data from the Panel Study of Tunisia Labor Market 2014 (TLMPS 2014). The Kaplan-Meier estimates of the survival function are presented (used) to analyze the determinants of unemployment duration. Results point (out) significant differences between men and women in the difficulty of getting a first job. These differences consist mainly in the following points. First, education appears as a highly positive factor in reducing the duration of unemployment, particularly for women. Second, the rural - urban gap continues to be significant in this context. Third, residents of regions with higher unemployment rates, all else equal, have longer duration of unemployment. In all regions, women have relatively longer duration of unemployment. Fourth, the unemployed persons from the age group 25-30 years have a higher probability of remaining unemployed. Fifth, married women have significantly longer duration than married men before finding jobs. These results may be useful and can improve the implementation of adequate policies on the Labor market of Tunisia by identifying vulnerable groups of persons that look for employment.
\end{abstract}

Keywords: unemployment duration, survival analysis, Kaplan - Meier estimator, Tunisia. 


\section{Introduction}

Tunisia currently suffers from remarkably high youth unemployment. The statistics indicate that the youth unemployment rate, at successive cyclic peaks, increased from 29.49 percent in 2010 to 35.12 percent in 2015 and 36.06 percent in 2016 (INS).

The increase in the youth unemployment rate at various times in the last few decades is mainly due to an increase of new entrants to the labor force on the first hand, and to a high duration of unemployment on the other hand; indeed, it takes most people a long time to find a job. This situation raises the question of how some persons take longer to get a job than others.

In order to properly design policies to (alleviate) address the growing problem of unemployment in Tunisia, it is important to understand how the probability of exiting unemployment varies with demographic and individuals' characteristics. In other words, it is essential to understand the path of people from school to work and the extent to which they can or cannot quickly find a job and how long it really takes to get employed.

Numerous statistics have been put in place in order to analyze determinants of unemployment and its dynamics. The empirical literature on unemployment duration is vast and encompasses a variety of themes. New analysis by Gontero and Weller (2017) shows that understanding the difficulties in the transition from school to work is not just a matter of analyzing the youth unemployment rate among first-time job seekers, since it is a more complex phenomenon that cannot be captured by a binary opposition between employment and unemployment. While the unemployment rate is a key indicator of the average severity of the problem for an entire population, it masks the dynamic nature of the labor market by failing to capture the length of time individuals spend unemployed. Following Ciucă and Matei (2010), unemployment duration is an important variable that explains the changes in labor market, and is generally used to model jobs creation, especially when analyzing the relationship among the employment, unemployment, and labor market exit flows. A labor market where few people become unemployed, but where they tend to remain unemployed for a very long time, is more insecure than one in which there are many more persons that become unemployed but remain in that position for a shorter period of time (Bajram, 2013, p. 36).

Theories explaining the unemployment duration are abundant in both the fields of sociology and economy. We distinguish three approaches. According to the Signalling Theory, long-term unemployment reduces one's motivation to search for employment (Vishwanath, 1989; Luijkx \& Wolbers, 2009). Long unemployment duration is perceived as a negative signal by potential future employers. Job search theory asserts that the transition or exit probability out of unemployment depends on two factors such as the probability that the worker receives a job offer and the probability that the job offer is acceptable. Human capital theory indicates that workers with higher levels of education move into employment more quickly than workers with less education (Devine \& Kiefer, 1991). The longer the schooling duration leads, the larger the number of occupations a worker can apply for.

This paper has two objectives. The first is to show that the time it takes to get a job after leaving school has longer-term effects on labor market outcomes. The second objective is to understand how the probability of exiting unemployment varies with individual characteristics (gender, education, age, etc.).

We focused on the analysis of the unemployment duration in Tunisia. The data used consisted in a sample of 1126 unemployment spells observed during the period 2005-2014. The sample was restricted to youth, aged 15 to 30 years. Less attention has been paid to determinants of unemployment duration. To our knowledge, this is the first study on the duration aspect of unemployment in Tunisia although the incidence of unemployment was considered by earlier studies (Boughzala, 2004, Marco \& Audrey, 2011, Haouas, Sayre, \& Yagoubi, 2012).

This paper is divided into five major sections: Section 2 provides a general theoretical framework and reviews the empirical literature on factors influencing the time taken for school leavers to enter their first job. Section 3 describes the Kaplan Meier method used to model time-tofirst-job. Section 4 discusses the data obtained from the panel survey of Tunisia Labor Market (TLMPS 2014) in order to construct a cross-section of durations of unemployment spells and present the results. Conclusions appear in section 5. 


\section{Theoretical and empirical considerations}

This section provides a general theoretical framework and a survey of the empirical literature. Theory of search on labor market explains why unemployed persons delay taking up of employment and the duration of unemployment. In this area many theories explaining the phenomenon of duration in unemployment and approaches are conducted.

We focus on four widely cited theories focusing on employers' perceptions: human capital theory, general signaling theory, and job search theory.

The abilities and skills of the masses are called human capital. It determines the productivity of the economic growth and development of the different sectors. It has very positive effect on economic growth and economic development and it orients effects on the unemployment. Human capital is a best instrument to reduce the unemployment. Education is a key factor to promote the efficiency and capabilities of the masses. It is one of the main determinants for the youth unemployment rate. Several studies have been carried out to estimate the impact of human capital on unemployment. Results suggest that education is positively and significantly impact on employment level (Bashir et al., 2012, Chaudhary et al., 2010). When youth invest in their educations as a result they decrease their unemployment opportunity cost. Researchers conclude that rate of return to education and youth unemployment have positive relation.

Human capital is likely to depreciate in the case of long-term unemployment. A long duration of unemployment may have a demoralizing effect on human behavior. As a result, the unemployed may lose their skills and they may be less employable. One of the attempts to explain the sources of duration of unemployment emphasizes the depreciation of human capital. This explanation is referred to as duration theory or human capital theory (Mikhail, Eberwein \& Handa, 2003).

Christelle et al. (2010) estimate the relationship between long-term unemployment and education. They find that the level of human capital has a negative effect on unemployment; the chances of a person to be remain in long-term unemployment decreases with increases in her/his educational level. They show that younger workers (20-30 years) are more beneficial than older workers (50-65 years).

Evans and Koch (2007) examine the relationship between unemployment and human capital. They conclude that levels of education tend to increase the average employment duration.

Ferral (1997) finds that people with lower levels of educational attainment receive job offers less often than those with higher levels of attainment, leading to longer expected unemployment duration for those with lower levels of attainment.

Similarly, findings from empirical studies indicate that individuals with higher levels of educational attainment have a higher employment probability, and consequently a shorter period of unemployment (Nielsen et al., 2001, Dolton et al., 1994).

To conclude the literature section, we can say that the education improved the rate of unemployment decreases and vice versa. Indeed, education is negatively related to unemployment. Human capital (education) has significant and strong impact on unemployment in short run and in long run.

The standard job search theory provides a valuable framework for the analysis of unemployment's duration. According to this approach, the probability of leaving unemployment is the product of the probability of receiving a job offer times the probability of accepting it (Stigler, 1962; McCall, 1970; Mortensen, 1970).

Search theory considers unemployment duration as a searching process where job offers are received at a constant rate and where individuals sequentially search for a new job (see Mortensen 1970 and McCall 1970 for details of the basic framework).

A person looking for a job is confronted with a specific and known distribution of potential incomes. Variance of the income offers result from asymmetric information and different matching qualities. Usually, in search theory, the income distribution is taken as given and might be thought of as an a priori distribution that is revised while searching proceeds.

Using a duration model in the reduced form approach, Feinberg (1977) finds unemployment duration to be shortened with higher risk aversion. Unfortunately, the data set used by Feinberg does not contain a direct risk measure but instead builds on an index considering behavior in different risky situations, such as having insurance on cars. Cox and Oaxaca (2008) find in their empirical experiments that risk adverse people stop searching earlier, than risk neutral people, as proposed by job search theory. Schunk and Winter (2007) are interested in the reason for the earlier stopping of job search than proposed by standard job search theory by many people. They proposed two 
different explanations. One of them is the existence of risk aversion, while the other focuses on the existence of limited cognitive processing capacities. However, in their investigation they do not find evidence for risk aversion, but for loss aversion (Kahnemann \& Tversky, 1979).

Signaling theory is the collection of theories arguing that when people are confronted with limited information, they use this available information as a signal for other, unobserved factors (Vishwanath, 1989; Blanchard \& Diamond, 1994; Moscarini, 1997; Kroft, Lange \& Notowidigdo, 2013; Eriksson \& Rooth, 2014).

According to this theory, long-term unemployment might signal unobserved productivity determinants (e.g. lower intellectual or social capabilities) (Vishwanath, 1989) or lower motivation (Luijkx \& Wolbers, 2009). This second channel is thereby closely related to Arrow's (1973) model of statistical discrimination.

A final theory stipulates that potential employers follow the behavior of other employers when making the decision to invite someone for a job interview. This is termed rational herding (Oberholzer-Gee, 2008). One such factor from which employers might infer the screening behavior of their colleagues is job candidates' unemployment duration. If this unemployment duration is relatively long, recruiters might conclude that other employers have found the candidate's productivity to be low. A long - term unemployment might thus, also following this theory, lead to the conclusion that it is unprofitable to hire the candidate. The last three theories are in fact a broad sense application of the signaling theory. Indeed, apart from the direct signals of unemployment mentioned, the unemployment spell might signal (a) skill loss, (b) lower trainability and (c) rejections by other employers.

Possible theoretical explanations at the employee side are mainly psychological in sort. One possibility is that a long unemployment spell reduces one's motivation to search for employment. Clark, Georgellis and Sanfey (2001) show that the unemployed can become indifferent to the prospect of becoming employed after a lengthy unemployment spell. Arulampalan, Booth and Taylor (2000) argue that the long-term unemployed will reduce their reservation wage and will be more willing to accept low-quality jobs, which are more likely to be unstable. Mortensen (1986) points towards the institutional side and states that unemployment insurance constitutes a disincentive to search for the long-term unemployed.

An unified model integrates employer and employee-search procedures to explain the determinants of time-to-first-job (Warner et al., 1980). An explanation of the duration of unemployment spells should account for all three factors; lower level of human capital and, therefore, productivity compared to adults, which makes employers prefer adults. Individuals seeking a job must first locate a firm with a job vacancy, a prolonged transition process may be the consequence of employers being dissatisfied with a school leaver's qualification or a worker being unhappy about the quality of the positions currently offered in the market. The probability of leaving unemployment is the product of these three factors.

More specifically, it is the level of education relative to that of other labor market entrants that leads to a successful transition from school to work, as this determines an individual's position in the labor queue (Thurow, 1975).

Existing studies report a number of key determinants for this individual-level unemployment duration. Gradin, Canto, and del Rio (2012) find that the economic slowdown increased unemployment durations in certain EU countries, in Spain, Portugal, Greece, the UK, France, Italy, and Poland.

Previous studies have identified factors that influence the time-to-first-job after leaving school.

A factor found to have a substantial influence on the time the time it takes to get first job is educational attainment. According to earlier studies (Chuang, 1999, Nielsen et al., 2001), the longer that school leavers stay unemployed, the less likely they are to become employed. The time-to-firstjob is influenced by the duration of a school leaver's time spent in the state of non-employment.

Several studies indicate that gender is also related to unemployment duration. Females take longer to find their first job than males (Eylandet al., 1989 Lassibille et al., 2001, Genda \& Kurosawa, 2000).This result indicates that females and males should be analyzed separately. 


\section{Survival analysis of unemployment duration}

The aim of this section is to contribute to a better understanding of the factors which affect unemployment duration by investigating the relation between unemployment duration, and personal and labor market characteristics, using a Kaplan Meier method. Unemployment duration represents the length of time spent by unemployed people who have been continuously looking for an occupation. Mean duration is the average computed from single weeks (months or years) of unemployment. We provide some interesting details about youth unemployment duration (unemployed, inactive and not in education or training, with the aim of looking for work later).

\subsection{The Kaplan-Meier method}

Job search theory provides a useful framework for the analysis of duration to first job. Under this theory, individuals start their job search process immediately after leaving school.

The conditional probability that an individual school leaver will be employed in a given interval $(t, t+d t)$ is the product of the probability of receiving a job offer and the probability of then accepting it. The latter is the probability that the wage offer exceeds the reservation wage.

Kaplan-Meier Method, called the product-limit estimator, was developed by Edward L. Kaplan and Paul Meier. This method is used in medical studies where "death" and "alive" are used frequently. In the context of this paper, we replace "death" by employment and "alive" by unemployed.

The main variable of interest is the duration of unemployment, which is stochastic and denoted by $\mathrm{T}$, where $\mathrm{T}$ is a random variable called lifetime or survival time (1958).

In the empirical literature, $\mathrm{T}$ is taken as a continuous random variable (for example Grogan and van den Berg, 2001) for convenience. However, $\mathrm{T}$ is, in practice, usually available in monthly form (or grouped into time intervals). The theoretical developments of the hazard function and the associated likelihood function with the grouped duration data, are provided by Prentice and Gloeckler (1978), Kiefer (1988) and Sueyoshi (1995). In this paper we take grouped nature of the unemployment duration data we have explicitly into account. We now briefly describe the alternative specifications about the hazard rate following Sueyoshi (1995).

$F(t)=\operatorname{Pr}(T<=t)$, is the cumulative distribution function of $\mathrm{T}$, where $t$ denotes realization of $T$, and $S(t)=1-F(t)$ is the survivor function of $\mathrm{T}$.

$\mathrm{S}(\mathrm{t})$, the survival function is the probability of an individual surviving (remaining unemployed) at $t$ units of time from the beginning of the study

In general, the survival function $S(t)=P(T>t)$ ) gives the population's probability of surviving beyond $t$, the cumulative distribution of T is $F(t)=P(T \leq t)$ and the probability density function is $f(t)=\frac{d F(t)}{d t}$. This means the survival function $S(t)=1-F(t)$.

The Kaplan-Meier estimator is a simple method allowing the computation of an estimated survival function in the presence of right censoring.

$$
S(k)=S(k-1) p_{k}=p_{1} \times p_{2} \times \ldots \times p_{k}
$$

$p_{k}$ is the proportion of individuals surviving at least the $k$-th year after they have survived $(k-1)$ years.

Denotes $d_{i}$ as the number of observed events at time $t_{i}$, and $n_{i}=d_{i}+r_{i}$ is the number of subjects whose event time is not less than, where $r_{i}$ is the number of subjects alive after time $t(i)$.

The PL estimate of survival probability at time $t$ was proposed by Kaplan-Meier as: $S(t)=\prod_{t_{i} \leq t}\left(1-h_{i}\right)=\prod_{t \leq t}\left(1-\frac{d_{i}}{n_{i}}\right)$ if $t>$ the first uncensored event time and $S(t)=1$ before that.

We are interested in the following question. What is the probability that the spell of unemployment will end in the next short interval of time, say $d t$, given that it has lasted until time $t$. 
This defines the hazard function which is a very popular way of analyzing duration data for several reasons. These models can handle censored durations; variables that change over time and allow examination of duration dependence (see Ham \& Rea, 1987).

\subsection{The Data Set}

The sample is restricted to individuals aged between 15 and 30 years, with information concerning personal characteristics. Table 1 gives the frequencies and percentages for different categories of unemployment status. This table shows that, of the 1126 individuals in the study, 718 individuals remained unemployed, and 408 individuals became employed.

The high percentage of young unemployed registered (right - censored data) shows that young people cannot find a job after finishing their studies, as the labor market in the country is not ready to receive them.

\begin{tabular}{lcc} 
Table 1: Employment status of unemployed individuals & \\
\hline Right - censored data & Frequency & Percent \\
Completed observation & 718 & 63.77 \\
Total & 408 & 36.23 \\
\hline
\end{tabular}

Source: TLMPS 2014 and authors' calculation

The available information for each individual is: the beginning date of unemployment spell, gender, age, education, place of residence (urban or rural), region and marital status. The variables used in the analysis of unemployment duration are presented in annex (Table A1).

Details of the categories of explanatory variables are listed in Table 2.

In data processing we have grouped persons by their educational level in five groups: low group (Illiterate, Read and Write), less than intermediate (primary school), intermediate(secondary school), above intermediate-preparatory (university short cycle), university $\boldsymbol{\&}$ above (university long cycle and post-graduate). We distinguish between two age groups (15-24 years and 25-30 years).

We have grouped persons by three regional residencies: Greater Tunis, Western regions, and Eastern regions. In Tunisia, since several years the West has become one of the poorest regions. It registers of the highest rates of poverty in the country, same thing for the level of unemployment and illiteracy.

Regarding the variable gender, of 52.40 percent of women registered in our database 22.88 percent leave unemployment by becoming employed, and of 47.60 percent of men registered, 50.93 percent leave unemployment by becoming employed.

The differences between men and women, although existent, don't allow us to point out a clear advantage for one of these two categories.

As for age, for the group 15-24 years 25 percent leave unemployment by becoming employed and 39.02 percent of the young people aged between 25-30 years registered in the database leave unemployment by becoming employed.

Regarding the level of education, 11.38 percent registered in the database are university graduates, 30.16 percent leave unemployment by becoming employed. 16.89 percent graduated only from secondary school, 32.09 percent become employed. 7.41 percent are without education, only 29.27 percent leave unemployment by becoming employed.51.40 percent graduated only from primary school (less than intermediate), 40.42 percent become employed. 12.92 percent of persons graduated from above intermediate-preparatory (university short cycle), 35.66 percent leave unemployment by becoming employed.

Registered unemployment rates in these regions clearly indicate the East-West distribution. Eastern regions have the lowest unemployment rates.

The order of regions is the same regardless of which unemployment rate is taken into account. The difference is only in the levels as noted above for the aggregate data.

The reasons for the East-West distribution of unemployment rates can be mainly attributed to different patterns of economic activity in the former system.

In the former system, eastern regions were characterized by a large share of manufacturing activities, specifically specialized in labor intensive industries, such as textile industry. 
In rural area there is a high level of youth unemployment, practically one of every three young person is employed.

\begin{tabular}{|c|c|c|c|c|c|}
\hline $\begin{array}{l}\text { Explanatory } \\
\text { variable }\end{array}$ & Categories & $\begin{array}{c}\text { Percentage } \\
\text { of total } \\
\text { sample }\end{array}$ & $\begin{array}{l}\text { Percentage of } \\
\text { completed } \\
\text { observation } \\
\text { (employed) }\end{array}$ & $\begin{array}{c}\text { Percentage } \\
\text { Right - } \\
\text { censored data } \\
\text { (unemployed) }\end{array}$ & Total \\
\hline & & & 36.23 & 63.77 & 100 \\
\hline \multirow[t]{3}{*}{ Gender } & Male & 47.60 & 50.93 & 49.07 & 100 \\
\hline & Female & 52.40 & 22.88 & 77.12 & 100 \\
\hline & Total & 100 & & & \\
\hline Marital & Single & 87.30 & 38.66 & 61.34 & 100 \\
\hline \multirow[t]{2}{*}{ Status } & Married & 12.70 & 19.58 & 80.42 & 100 \\
\hline & Total & 100 & & & \\
\hline \multirow[t]{3}{*}{ Age } & $15-24$ & 69.27 & 35 & 65 & 100 \\
\hline & $25-30$ & 30.73 & 39.02 & 60.98 & 100 \\
\hline & Total & 100 & & & \\
\hline \multirow{8}{*}{$\begin{array}{l}\text { Education } \\
\text { status }\end{array}$} & Illiterate $\&$ read and & 7.41 & 29.27 & 70.73 & 100 \\
\hline & write & & & & \\
\hline & Less than & 51.40 & 40.42 & 59.58 & 100 \\
\hline & intermediate & & & & \\
\hline & Intermediate & 16.89 & 32.09 & 67.91 & 100 \\
\hline & Above Intermediate & 12.92 & 35.66 & 64.34 & 100 \\
\hline & University \& Above & 11.38 & 30.16 & 69.84 & 100 \\
\hline & Total & 100 & & & \\
\hline \multirow{3}{*}{$\begin{array}{l}\text { Area of } \\
\text { residence }\end{array}$} & Urban & 42.36 & 41.09 & 58.91 & 100 \\
\hline & Rural & 57.64 & 32.67 & 67.33 & 100 \\
\hline & Total & 100 & & & \\
\hline \multirow[t]{4}{*}{ Region } & Greater Tunis & 16.87 & 34.74 & 65.26 & 100 \\
\hline & East & 49.20 & 42.60 & 57.40 & 100 \\
\hline & West & 33.93 & 27.75 & 72.25 & 100 \\
\hline & Total & 100 & & & \\
\hline
\end{tabular}

Source: TLMPS 2014 and authors' calculation

For the analysis we express the duration of unemployment in years, we have its minimum duration - 0 years and- its maximum duration of 10 years, with an average of 4.13 years.

Transition length is presented in years and calculated by subtracting education exit date from the start date of a young person's current economic activity. All in all, what is evident from the table is that, not only the Tunisian youth face higher unemployment incidence, but longer unemployment spells as well. Based on the ILO criteria, if average unemployment duration lasts more than a year, it is said to be a long-term unemployment. By this definition, it appears that majority of the Tunisian school leavers face a very long-term of unemployment, with a significant human capital and skill losses.

Transition duration is particularly longer for young men living in rural environment (4.21 years) against (4.17 years) for those living in urban areas. Furthermore, transition duration is particularly lower for young women living in an urban environment (4.69 years) against (5.46 years) for those living in rural areas.

Women, however, experienced a longer transition than men in the West region (5.34 years versus 3.92 years), and in Greater Tunis (5.29 years versus 4.92 years), and the East region (4.93 years versus 4.11 years) as seen in table 3.

The data also show that, on average, the transition for men is shorter than it is for women. In other words, transition length increases to 1 year between men and women.

Married transited men had the shortest transition (3.46 years), while married women had the longest (6.50 years).

Marital status does affect the duration of unemployment. Its impact is non negligible, implying a decrease in the average duration of unemployment until finding a job (about 1 year for men).

The marital status effect is the result of an interaction between two different explanations. On the one hand, being married may increase the job search intensity of a spouse if the other has lost his/her job or is experiencing job reallocation. On the other hand, for women, being married may 
reduce unemployment duration by increasing the probability of leaving unemployment towards inactivity, if a household income is adequately supported by men.

\begin{tabular}{|c|c|c|c|c|c|c|c|c|c|c|}
\hline & \multirow[b]{2}{*}{ All } & \multicolumn{2}{|c|}{ Residence area } & \multicolumn{3}{|c|}{ Region } & \multicolumn{2}{|c|}{ Age groups } & \multicolumn{2}{|c|}{ Marital status } \\
\hline & & Urban & Rural & $\begin{array}{l}\text { Greater } \\
\text { Tunis }\end{array}$ & East & West & $\begin{array}{c}\text { Age } \\
15-24\end{array}$ & $\begin{array}{c}\text { Age } \\
25-30\end{array}$ & Married & Single \\
\hline Male & $\begin{array}{c}4.19 \\
(2.73)\end{array}$ & $\begin{array}{c}4.17 \\
(2.78)\end{array}$ & $\begin{array}{c}4.21 \\
(2.68)\end{array}$ & $\begin{array}{c}4.92 \\
(2.74)\end{array}$ & $\begin{array}{c}4.11 \\
(2.89)\end{array}$ & $\begin{array}{c}3.92 \\
(2.38)\end{array}$ & $\begin{array}{c}4.13 \\
(2.71)\end{array}$ & $\begin{array}{c}4.37 \\
(2.77)\end{array}$ & $\begin{array}{l}3.46 \\
(1.2)\end{array}$ & $\begin{array}{c}4.22 \\
(2.79)\end{array}$ \\
\hline Female & $\begin{array}{c}5.13 \\
(2.94)\end{array}$ & $\begin{array}{c}4.69 \\
(2.82)\end{array}$ & $\begin{array}{c}5.46 \\
(3.09)\end{array}$ & $\begin{array}{c}5.29 \\
(2.65)\end{array}$ & $\begin{array}{c}4.93 \\
(2.93)\end{array}$ & $\begin{array}{c}5.34 \\
(3.19)\end{array}$ & $\begin{array}{c}4.89 \\
(2.87)\end{array}$ & $\begin{array}{c}5.57 \\
(3.05)\end{array}$ & $\begin{array}{c}6.50 \\
(3.38)\end{array}$ & $\begin{array}{c}4.75 \\
(2.88)\end{array}$ \\
\hline
\end{tabular}

Source: TLMPS 2014 and authors' calculation.

Table 4 presents the beginning and end of the transition period (secondary and postsecondary education to job market entry).

For young men with secondary education (Intermediate), the average transition duration is 3.79 years. For this category, women suffer the most from long professional transition duration. Average transition duration is 5.40 years. Men with post-secondary education, transition duration is shorter than that of men with university education.

For post-secondary education, transition duration for women is shorter than for men.

Youth living in urban areas, although leaving the school system at the same age as their counterparts in rural areas, access to their first job at 4.6 years on average for people with a secondary education and at an average of 2.29 years for youth with post-secondary education.

Young women with university education need approximately 2.5 years to ensure employment. In contrast, for men the average duration of unemployment until finding a job is of 2.8 years.

Table 4: Average unemployment duration by gender and level of education (years)

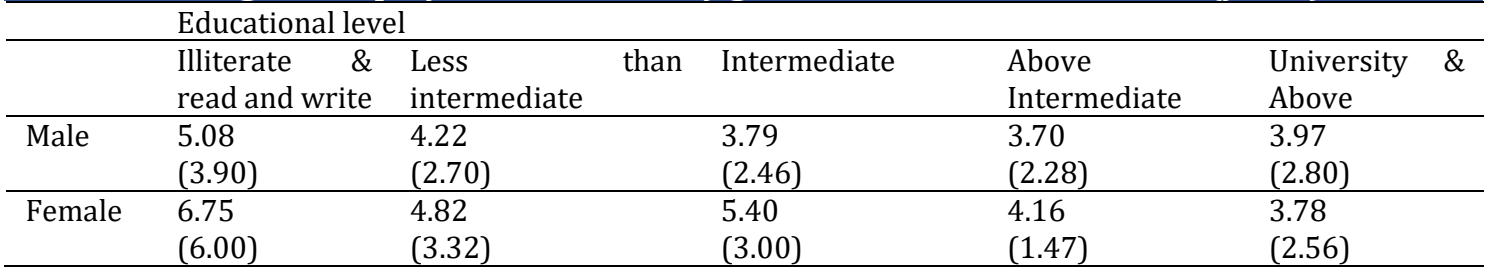

Note: The reported means are calculated as rmeans using STATA

The results indicate that:

The gender gap, age, education, region and marital status are significant. These variables affect the duration of unemployment.

Average transition duration is shorter for the more educated young people than for the other categories. Shortly after leaving school, youth may have found jobs.

These results indicate that transition differs between urban and rural areas, between men and women and between geographic regions. These results highlight also that transition from school to work is more affected by education level.

The above described database allows us to take a look into different characteristics of duration of unemployment by gender:

1. According to residence area, in urban and rural regions men have similar durations of unemployment. Women living in the rural region are in a worse position. Women need on average 2 months in urban region more than men to find a new job. It takes longer for men to get employed in rural region (5 months).

2. Regarding age, the unemployed aged between 15 and 24 years are in the worst position. It is interesting to note that young women unemployed (25-30 years) have a relatively long duration of unemployment.

3. As for level of education, the length of unemployment in general decreases with higher levels of education with a few exceptions. The longest unemployment was experienced by those with no education. Also for men with a higher level of education (university) who experienced a longer unemployment period than those with intermediate and above intermediate levels of education. 
4. However, education is markedly more important for women than men.

We propose to complement this analysis by using the Kaplan - Meier method which can take into account "censored" data. During the recent years these techniques have gained popularity in the social sciences to model the length of unemployment spells and the strike duration.

\section{Results of the Kaplan-Meier}

The Kaplan-Meier technique is a nonparametric method for estimating time-related events by creating a new variable that represents people reaching the employment event, and those failing to reach that event (employment). Its curve can consider "censored" data losses from the sample before the final outcome is observed.

In this section, we discuss the results of this method used to estimate the survival probabilities and to compare survival curves by categories of factor variables.

The Kaplan Meier estimator of the survival function for all youth (employment and unemployment) is presented in figure 1 which illustrates the survival curve for unemployment duration. Points on this curve estimate the proportion of individuals who remained unemployed over time.

The curve shows that the probability of survival is 0.8 in the first year of our study period. We say that the probability of finding a job and leaving the unemployment situation is very high for new comers.

Figure 1: Survival function estimates for all unemployed

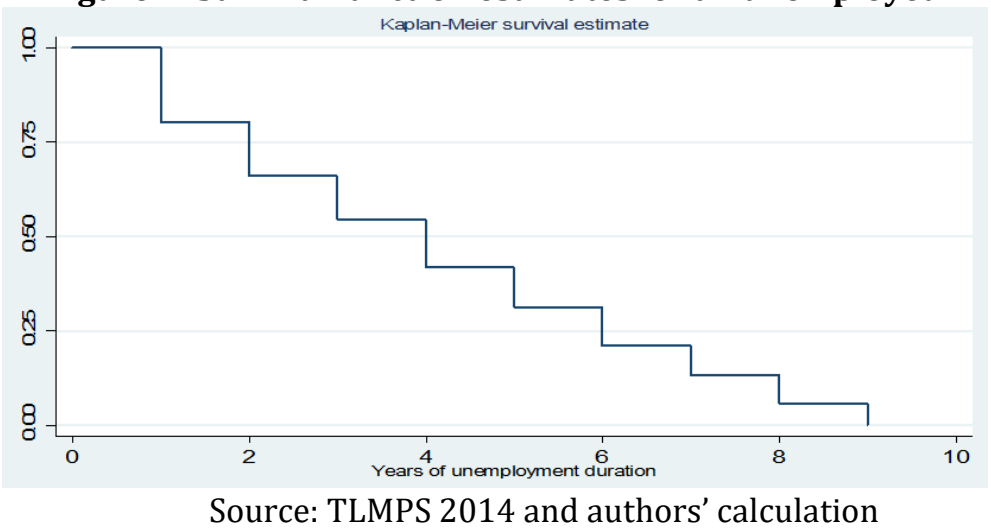

The survival function indicates the proportions of people who survive unemployment as time proceed. Figure 2 shows that there are significant differences with an advantage for men over women. The unemployed men have a far better position in the labor market because the women have longer unemployment durations than men

Figure 2: Survival function by gender

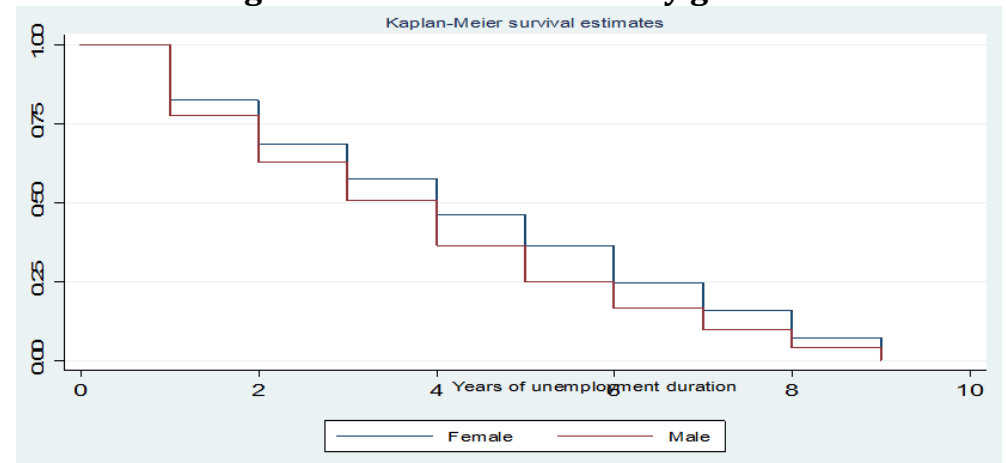

Source: TLMPS 2014 and authors' calculation

Another concern of this study is to investigate unemployment duration by area of residence. Figure 3 shows the corresponding curve for rural areas is higher than that of urban areas, meaning 
that for the same period, the probability of remaining unemployed is higher for rural than for urban areas.

For men, figure 3 shows that there are minor differences with an advantage for men in urban areas over men in rural areas. However, beyond 5 years and 6 years of unemployment, the probability of remaining unemployed is the same for both urban and rural areas.

Unemployed women from rural areas have a higher probability of remaining unemployed. We believe that it may be more difficult for them to adapt to the new labor market conditions.

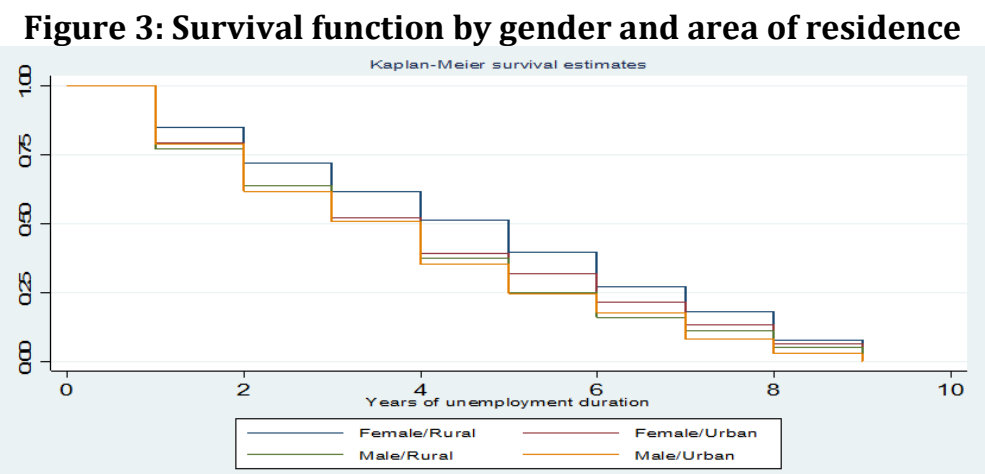

Source: TLMPS 2014 and authors' calculation

Concerning educational level, we have considered five educational levels. In figure 4 are presented the Kaplan Meier estimators of the survival curves on educational levels.

The figure shows that major differences in the survival curves appear after the two year of unemployment.

Higher education has a positive effect on probability of leaving unemployment. We can notice in the figure that for the group 4, high education level, and the probability of unemployment at time t or later decreases much more rapidly for women. For men, the educational level has little influence on the survival rates.

One of the reasons for this pattern is the fact that more educated individuals are more selective in accepting job offers and may look for a job for a longer period.

Figure 4: Survival function by gender and education level

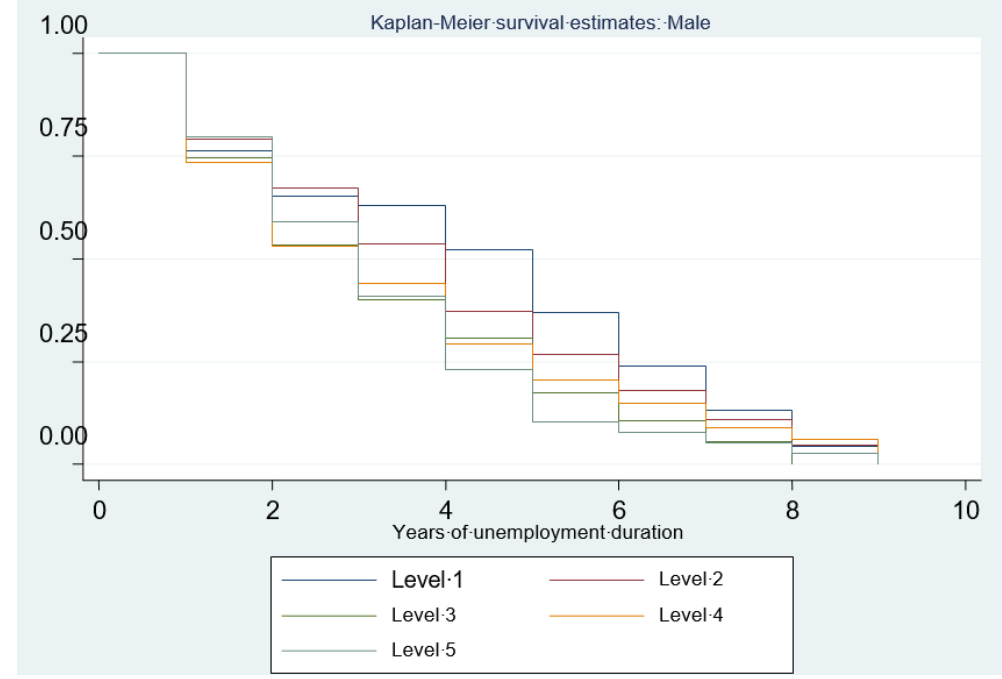




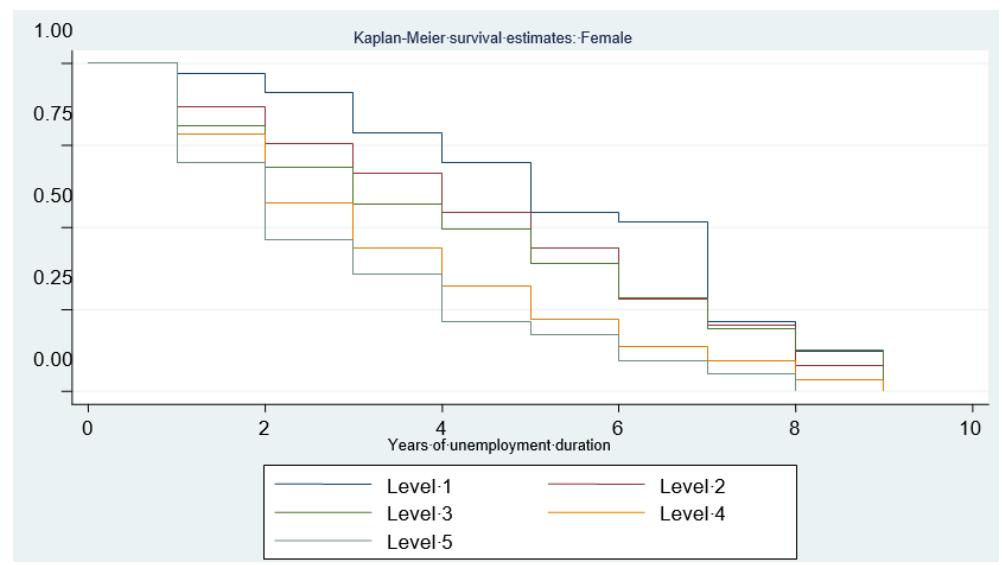

Source: TLMPS 2014 and authors' calculation

Level 1: low group

Level 2: less than intermediate,

Level 3: intermediate

Level 4: above intermediate-preparatory

Level 5: university \& above

Considering only these 3 regions we obtained a survival function which shows that the survival rate in Greater Tunis in the first year is 0.7 for men and is 0.85 for women

Figure 5 shows a significant regional unemployment differential. Each region has another survival function with a different behavior. For example, in the west region men have the lowest unemployment duration while women have the highest unemployment duration.

Thus, in East region, form men the probability of remaining in unemployment after the first year is under 0.8 whereas for women this probability is close to 0.9

Unemployment duration might be lower if region were more fully developed, allowing more workers to migrate to regions where unemployment was relatively low.

Regional variation in labor market opportunities also yields significant impacts on the length of time individuals can expect to remain unemployed.

Individuals residing in the West region can expect unemployment durations between 11 and 18 per cent longer than those residing in the East region.

We note that the higher the regional unemployment rate, the more time individuals spend unemployed before leaving the labor force.

Figure 5: Survival function by gender and region

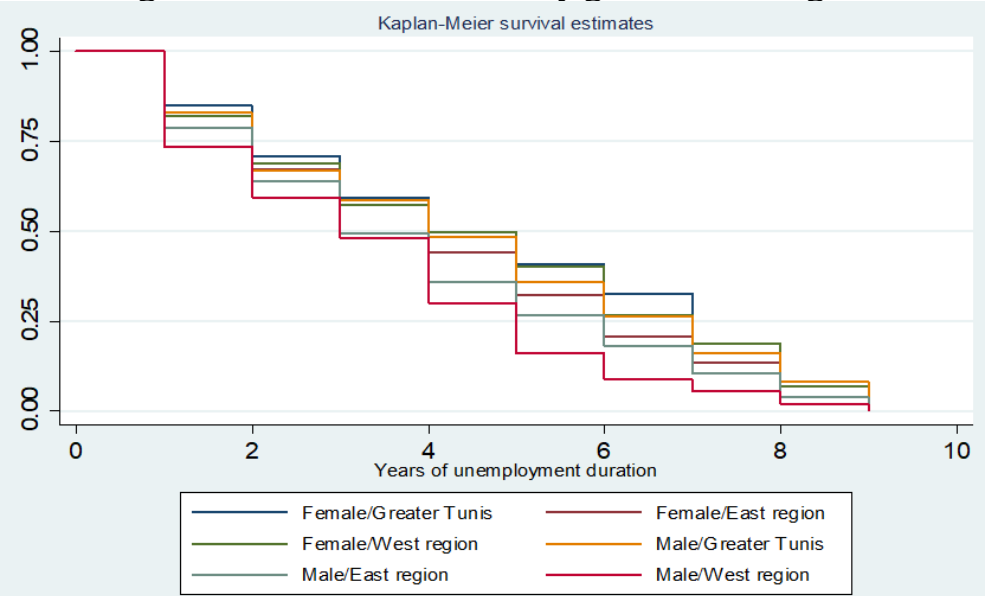

Source: TLMPS 2014 and authors' calculation

In figure 6 there is presented the survival curve for the age groups 15-24 years and 25-30 years. We can notice that within four unemployment years the men aged groups 15-24 years holds a 
net advantage as compared to the other age groups (25-30 years). After four unemployment years, the men aged 25-30 years hold a net advantage as compared to the other.

Age and gender can be considered as influence factors of the unemployment survival probabilities, and consequently of the unemployment duration.

It seems that for the age group 25-30 years it is the most difficult to find a job and that it is easier for those in the age group 15-24 years.

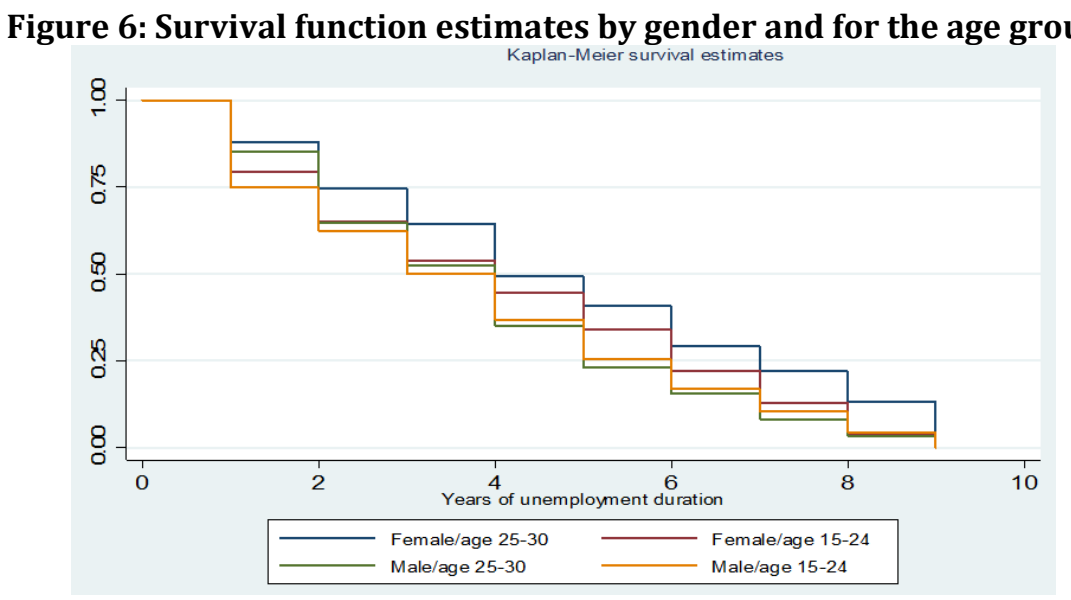

In Figure 7, we can notice that probabilities of staying unemployed for the young pers ons are smaller for single male.

The interaction of unemployment duration with gender and marital status reveals a significant difference between single men and married men.

For single women, the probabilities of staying unemployment after fourth years of unemployment are smaller. In contrast, married women are found to experience significantly longer unemployment spells before exiting to a job.

The survivor function for non-married men declines more steeply than women implying that unemployed men find jobs sooner than unemployed women.

As figure 7 shows, a married woman can expect to remain unemployed over 3 years longer before finding a job, compared to a married man.

Figure 7: Survival function by gender and marital status

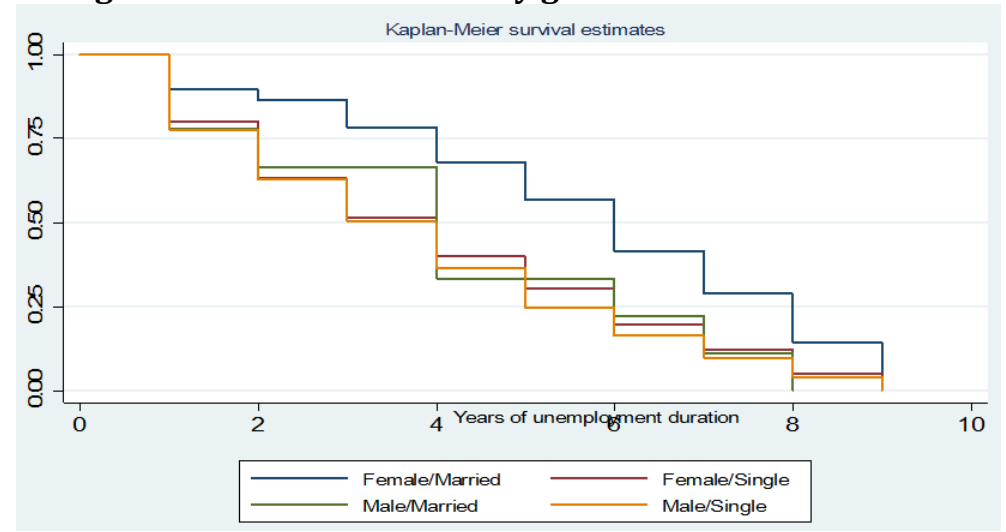

Source: TLMPS 2014 and authors' calculation

We can notice that the probabilities of being unemployed are different by age, place of residence, unemployment benefit, and unemployed category groups. The differences among the considered groups have been tested with the Log-Rank test (Mantel and Haenszel, 1959) and the results of the testing show that survival probabilities are significantly different by age, unemployment benefit and unemployed category groups.

In order to confirm the results obtained graphically from the Kaplan-Meier estimates of the survival functions, we used the log rank test with Chi-Squared distribution under the null hypothesis which that curves should be the same for the two levels of a factor. 
For gender, area of residence, and education level variables, the highly significant $\mathrm{p}$-values ( $\mathrm{p}$ value $=0.000$ ) confirm the results that curves are different (Table A2 in Appendix).

From the results of the survival analysis developed on a database that consists of information about the individuals during 2005-2014 in Tunisia, we may conclude that:

- The unemployed persons with higher education are advantaged on the labor market duration;

- There are significant differences between women and men, concerning the unemployment

- Average unemployment duration is high in rural areas, for women,

- The unemployed persons from the age group 25-30 years have a higher probability of remaining unemployed; we think that it may be more difficult for them to adapt to the new labor market conditions;

- The survival curves are different in the analyzed regions; we must investigate which factors are causing these differences.

We can interpret the seemingly contradictory evidence on the effect of regional unemployment duration. We find that in the short run weaker labor market conditions pull students out of the region.

Labor market conditions explain the migration well.

These findings are consistent with our story on the effects of labor market conditions on migration decisions. Weaker labor market conditions and lower wages increase the likelihood that young men stay at home with their parents, as well as remain in school.

My interpretation of the results reported in figure 4 is that in favored regions (East region and Greater Tunis) youth endowed with specific human capital are therefore willing to go through long unemployment spells in order to find a job in the same occupation. However, rural youth and western region youth which continue to face major disadvantages in education, employment and in the transition from education to employment, decide to migrate to the most favored regions.

The migration movement towards the favored regions is composed of a younger group than in the past, and mainly by men.

\section{Conclusions and recommendations}

In this paper, under the assumption that the distribution of unemployment duration is not known, we use the Kaplan - Meier method to estimate the probability of staying unemployed.

Identifying the role of individual characteristics and geography has important implications for policy. Economic policies should be targeted at altering those characteristics observed to exercise significant effects.

The survival functions are graphically represented by the Kaplan - Meier survival curves. The results of basic data analysis of the duration of unemployment spells curves show that:

- The duration of unemployment is primarily attributable to the demographic and personal characteristics of the unemployed.

- Women have been affected more than men by unemployment in Tunisia.

- The unemployed with the higher education have better opportunities in the labor market while youth with low level of education registers the lowest employment probability.

- Location and level of education appear to affect the length of an unemployment spell for both males and females. Urban youth find job more quickly than rural youth.

- Unemployment duration is on average the smallest for men, for individuals living in urban areas, for men living in west region and women living in East region.

These results may be useful to policy makers, both for the public and private sectors, and to employers in general.

It has been observed that employment among young males is the main reason for internal migration in Tunisia. Youth migration is a challenging and neglected phenomenon.

Recognition that the existence of regional influences is important suggests that, in order to increase the employability of the unemployed, microeconomic supply-side policies need be complemented with more macroeconomic demand-led management. These policies can be designed to encourage local employment initiatives and implement the appropriate policies for the region to benefit from such initiatives. These measures should provide solutions that would promote regional development and reduce territorial disparities. 


\section{Appendix A. Supplementary material}

Supplementary data associated with this article can be found, in the online version, at https://doi.org/10.14254/jems.2020.5-2.5

\section{Citation information}

Kriaa, F., Bouhari, M., \& Mathlouthi, Y. (2020). Determinants of unemployment duration for young men and women in Tunisia. Economics, Management and Sustainability, 5(2), 78-95. doi:10.14254/jems.2020.5-2.5

\section{References}

Arrow, K. (1973). The theory of discrimination, discrimination in labor markets. Achenfelter, A. Ress (eds.), Princeton-New Jersey.

Arulampalam, W. Booth, A., \& Taylor, M. (2000). Unemployment persistence. Oxford Economic Papers, $52,24-50$.

Bashir, F., Farooq, S., Nawaz, S., Bagum, M., Sandila, M. A. and Arshad, M. R. 2012. Education, Health and Employment in Pakistan: A Co-integration Analysis. Research on Humanities and Social Sciences, ISSN 2224-5766 (Paper) Vol.2, No.5,

Bajram, N. (2013). Distribution of Unemployment Spells and Survival Analysis: The Case of Bosnia and Herzegovina. Southeast Europe Journal of Soft Computing, 2(2).

Blanchard, O. J., \& Diamond, P. (1994). Ranking, unemployment duration, and wages. The Review of Economic Studies, 61(3), 417-434.

Borsic, D., \& Kavkler, A. (2009). Duration of regional unemployment spells in slovenia. Managing Global Transitions, 7(2), 123-146.

Boughzala, M. (2004). The Labor market in Tunisia: Study on the functioning of the labor markets in the Mediterranean Region and the implications for employment policy and training systems. University of Tunis.

Brown, S. J., \& Warner, J. B. (1980). Measuring security price performance. Journal of financial economics, 8(3), 205-258.

Carroll Nick. (2005). Explaining Unemployment Duration in Australia. Retrieved from http://econpapers.repec.org/article/blaecorec/v_3A82_3Ay_3A2006_3Ai_3A258_3Ap_3A2 8-314.htm

Chan, Y. H. (2004). Biostatistics 203. Survival analysis. Singapore medical journal, 45, 249-256.

Chaudhry, I. S., Malik, A., \& Faridi, M. Z. (2010). Exploring the causality relationship between trade liberalization, human capital and economic growth: Empirical evidence from Pakistan. Journal of Economics and International Finance, 2(9), 175-182.

Chuang, H. L. (1999). Estimating the determinants of the unemployment duration for college graduates in Taiwan. Applied Economics Letters, 6(10), 677-681.

Circelli, M., \& Oliver, D. (2012). Youth transitions: What the research tells us. A National Centre for Vocational Education Research Consultancy Report. Adelaide: National Centre for Vocational Education Research.

Ciucă, V., \& Matei, M. (2010). Survival analysis for the unemployment duration. In Proceedings of the 5th WSEAS International Conference on Economy and Management Transformation (EMT'10), I, pp. 354-360;

Clark, A., Georgellis, Y., \& Sanfey, P. (2001). Scarring: The psychological impact of past unemployment. Economica, 68(270), 221-241.

Garrouste, C., Kozovska, K., \& Arjona Perez, E. (2010). Education and long-term unemployment. doi:10.2788/28401. 
Babucea, A. G., \& Danacica, D. E. (2007). Using Kaplan-Meier curves for preliminary evaluation the duration of unemployment spells.

Dănăcică, D.E., \& Babucea, A.G. (2010). Using survival analysis in economics. Scientific Annals of the AlexandruIoanCuza University of Iaşi, pp. 439-450.

Daniela-Emanuela, D., \& Cîrnu, D. (2014). Unemployment duration in rural Romania. Procedia Economics and Finance, 15, 1173-1184.

Devine, T. J., Devine, T. J., \& Kiefer, N. M. (1991). Empirical labor economics: The search approach. Oxford University Press on Demand.

Dolton, P., \& O'Neill, D. (1996). Unemployment duration and the restart effect: some experimental evidence. The Economic Journal, 106(435), 387-400.

Dolton, P. J., Makepeace, G. H., \& Treble, J. G. (1994). The Youth Training Scheme and the school-towork transition. Oxford Economic Papers, 629-657.

Kaplan, E., \& Pau, M. (1958). Incompiete (observations). Journal of the American Statistical Association, 53(282), 457-481.

Eriksson, S., \& Rooth, D. O. (2014). Do employers use unemployment as a sorting criterion when hiring? Evidence from a field experiment. American economic review, 104(3), 1014-39.

Evans, R. W., \& Koch, T. G. (2007). Human Capital, Unemployment Duration and Individual Heterogeneity. University of Texas at Austin.

Eyland, E. A., \& Johnson, L. W. (1989). The Transition from Full-Time Study to Work. Australian Journal of Statistics, 31(1), 213-225.

Feinberg, R. M. (1977). Risk aversion, risk, and the duration of unemployment. The Review of Economics and Statistics, 264-271.

Ferrall, C. (1997). Unemployment Insurance Eligibility and the Scholl-to-Work Transition in Canada and the United States. Journal of Business \& Economic Statistics, 15(2), 115-129.

Foley, M. C. (1997). Determinants of unemployment duration in Russia. Economic Growth Center. Discussion Paper No. 779. Yale University, August.

Genda, Y., \& M. Kurosawa. (2000). Transition from school to work in Japan. Paper presented at NBER conference on Unemployment.

Gontero, S., \& Weller, J. (2017). Consideraciones para aumentar la participación de los trabajadores por cuenta propia en los sistemas contributivos de protección social en América Latina. Macroeconomics of Development series, No. 189 (LC/TS.2017/69), Santiago, Economic Commission for Latin America and the Caribbean (ECLAC), August.

Gradín, C., Cantó, O., \& del Río, C. (2012). Measuring employment deprivation among households in the EU. Society for the Study of Economic Inequality (ed.), ECINEQ Working Paper Series.

Greene, W. H. (2003). Econometric analysis. Pearson Education India.http://www.info.umfcluj.ro/resurse/Laborator/Metodologie/LabStoma/Materiale/Cu rsMetodol

Katz, L. F., \& Meyer, B. D. (1990). The impact of the potential duration of unemployment benefits on the duration of unemployment. Journal of public economics, 41(1), 45-72.

Kroft, K., Lange, F., \& Notowidigdo, M. J. (2013). Duration dependence and labor market conditions: Evidence from a field experiment. The Quarterly Journal of Economics, 128(3), 1123-1167.

Lassibille, G., Gómez, L. N., Ramos, I. A., \& De la O Sanchez, C. (2001). Youth transition from school to work in Spain. Economics of Education Review, 20(2), 139-149.

Luijkx, R., \& Wolbers, M. H. (2009). The effects of non-employment in early work-life on subsequent employment chances of individuals in the Netherlands. European Sociological Review, 25(6), 647-660. 
Machado, J. A., Portugal, P., \& Guimaraes, J. (2006). US unemployment duration: Has long become longer or short become shorter?. IZA Discussion Paper No. 2174.

Stampini, M., \& Verdier-Chouchane, A. (2011). Labor market dynamics in Tunisia: the issue of youth unemployment. Review of Middle East Economics and Finance, 7(2), 1-35.

McCall, J. J. (1988). Economics of Information and Job Search. Quarterly Journal of Economics, 26(2) (June), 646-679.

Mikhail, O., Eberwein, C. J., \& Handa, J. (2003). Can Sectoral Shift Generate Persistent Unemployment in Real Business Cycle Models? (No. 0311004). University Library of Munich, Germany.

Mortensen, D. T. (1986). Job search and labor market analysis. Handbook of labor economics, 2(15), 02005-02009.

Mortensen, D. T. (1970). Job search, the duration of unemployment, and the Phillips curve. The American Economic Review, 847-862.

Narendranathan, W., \& Stewart, M. B. (1993). Modelling the Probability of Leaving Unemployment: Competing Risks Models with Flexible Baseline Hazards. Applied Statistics, 40(1), 63-83.

Nielsen, H. S., Rosholm, M., Smith, N., \& Husted, L. (2001). Intergenerational Transmissions and the School-to-Work Transition of Second-Generation Immigrants.

Nonyana, J. Z. (2015). Statistical modeling of unemployment duration in South Africa (Doctoral dissertation). University of South Africa, Pretoria,[online]. Available at: <http://uir.unisa.ac.za/handle/10500/20982>[Accessed 27 March 2017] gie.pdf.

Oberholzer-Gee, F. (2008). Nonemployment stigma as rational herding: A field experiment. Journal of Economic Behavior \& Organization, 65(1), 30-40.

Blanchard, O., J., \& Diamond, P. (1992). The flow approach to labor markets. The American Economic review, 82(2), 354-359.

Stigler, J. (1962). Information in the Labor Market. Journal of Political Economics, 70(5), (Oct.), 94105.

Schunk, D., \& Winter, J. (2009). The relationship between risk attitudes and heuristics in search tasks: A laboratory experiment. Journal of Economic Behavior \& Organization, 71(2), 347-360.

Tansel, A., \& Tasci, H. M. (2004). Determinants of unemployment duration for men and women in Turkey. Institute for Study of Labor (IZA), Discussion Paper No: 1258, Bonn: IZA.

Vishwanath, T. (1989). Job search, stigma effect, and escape rate from unemployment. Journal of Labor Economics, 7(4), 487-502.

$* * * * *$

Institut National de la Statistique : Enquête nationale sur la population et l'emploi 2012. (décembre 2013).

Observatoire National de l'Emploi et des Qualifications 2013: Rapport annuel sur le marché du travail en Tunisie; Décembre 2013 


\section{Appendix}

Table A1: The list of the variables used in the analysis of unemployment duration

\begin{tabular}{|c|c|c|}
\hline Variables & Expression & $\begin{array}{l}\text { Observations } \\
\end{array}$ \\
\hline $\begin{array}{l}\text { Duration } \\
\text { unemployment }\end{array}$ & $\begin{array}{l}\text { The difference between } \\
\text { the date of entry and the } \\
\text { date of leaving } \\
\text { unemployment }\end{array}$ & $\begin{array}{l}\text { The maximum value is } 0 \text { years and the maximum value } \\
\text { is } 10 \text { years. The mean value is, while the median } \\
\text { duration is }\end{array}$ \\
\hline The status of the person & $\begin{array}{l}\text { Two groups: } \\
\text { First Employment (1) } \\
\text { Unemployment (0) }\end{array}$ & \\
\hline Gender & $\begin{array}{l}\text { Dummy takes } 1 \text { for } \\
\text { male and } 0 \text { for Female }\end{array}$ & \\
\hline Age & $\begin{array}{l}\text { We grouped the ages } \\
\text { into } 2 \text { categories } \\
\text {-Age } 15 \text { - } 24 \text { years }(1) \\
\text { Age } 25-30 \text { years }(0)\end{array}$ & $\begin{array}{l}\text { The average age of the persons registered in } \\
\text { the database is } 38.4 \text { years, while the median is } \\
38.5 \text { years. The youngest unemployed person } \\
\text { is } 17 \text { years old and the oldest is } 63 \text { years old }\end{array}$ \\
\hline Marital status & & \\
\hline Education level & $\begin{array}{l}\text { The level of education } \\
\text { is grouped in } 5 \\
\text { categories } \\
\text { Educa1 } \\
\text { Educa2 } \\
\text { Educa3 } \\
\text { Educa4 } \\
\text { Educa5 } \\
\text { Urban (1), Rural (0) }\end{array}$ & $\begin{array}{l}\text { Out of the sample, } 39 \% \text { of total persons have } \\
\text { primary and secondary or vocational education, } \\
48 \% \text { of total persons have high school and post- } \\
\text { secondary education, and } 13 \% \text { of total persons } \\
\text { have tertiary education }\end{array}$ \\
\hline Region & $\begin{array}{l}\text { The region is grouped in } \\
\text { three categories: } \\
\text { Greater Tunis } \\
\text { East region } \\
\text { West region }\end{array}$ & $\begin{array}{l}\text { Western regions, such as; North West ( Jendouba, } \\
\text { Beja, El Kef and Siliana),Center West ( } \\
\text { Kairouan, Kasserine and Sidi Bouzid) and South } \\
\text { West (Gafsa, Tozeur and Kébili), Eastern regions } \\
\text { such as: } \\
\text { East ( Bizerte, Ariana, Manouba, Ben } \\
\text { Arous, Zaghouan and Nabeul), Center-East } \\
\text { (Sousse, Monastir and Mahdia), } \\
\text { East ( Sfax, Gabès, Médenine and Tataouine). }\end{array}$ \\
\hline
\end{tabular}

Source: Authors' presentation of the variables used in the paper 


\begin{tabular}{|c|c|c|c|c|c|c|c|c|}
\hline Gender & $\begin{array}{c}\text { Events } \\
\text { observed }\end{array}$ & $\begin{array}{c}\text { Events } \\
\text { expected }\end{array}$ & $\begin{array}{c}\text { Area of } \\
\text { residence }\end{array}$ & $\begin{array}{c}\text { Events } \\
\text { observed }\end{array}$ & $\begin{array}{c}\text { Events } \\
\text { expected }\end{array}$ & $\begin{array}{l}\text { Age } \\
\text { group }\end{array}$ & $\begin{array}{c}\text { Events } \\
\text { observed }\end{array}$ & $\begin{array}{c}\text { Events } \\
\text { expected }\end{array}$ \\
\hline Male & 536 & 458.16 & Urban & 477 & 442.72 & $\begin{array}{c}15- \\
\text { 24years }\end{array}$ & 781 & 734.45 \\
\hline Female & 590 & 667.84 & Rural & 649 & 683.28 & $\begin{array}{c}25- \\
\text { 30years }\end{array}$ & 346 & 391.55 \\
\hline \multirow[t]{3}{*}{ Total } & 1126 & 1126.00 & Total & 1126 & 1126.00 & Total & 1126 & 1126.00 \\
\hline & chi2(1) & 30.94 & & chi2(1) & 6.06 & & $\operatorname{chi} 2(1)$ & 11.50 \\
\hline & Pr $>$ chi2 & 0.0000 & & Pr $>$ chi2 & 0.0138 & & Pr $>$ chi2 & 0.0007 \\
\hline Marital Status & $\begin{array}{c}\text { Events } \\
\text { observed }\end{array}$ & $\begin{array}{c}\text { Events } \\
\text { expected }\end{array}$ & & & & & & \\
\hline Single & 943 & 913.51 & & & & & & \\
\hline Married & 143 & 212.49 & & & & & & \\
\hline \multirow[t]{3}{*}{ Total } & 1126 & 1126.00 & & & & & & \\
\hline & $\operatorname{chi} 2(1)$ & 41.74 & & & & & & \\
\hline & Pr $>$ chi2 & 0.0000 & & & & & & \\
\hline \multicolumn{2}{|l|}{ Region } & & & \multicolumn{2}{|l|}{$\begin{array}{c}\text { Events } \\
\text { observed }\end{array}$} & \multicolumn{3}{|c|}{$\begin{array}{c}\text { Events } \\
\text { Expected }\end{array}$} \\
\hline \multicolumn{2}{|l|}{ Greater Tunis } & & & \multicolumn{2}{|l|}{190} & \multicolumn{3}{|c|}{216.62} \\
\hline East & & & & \multicolumn{2}{|l|}{554} & \multicolumn{3}{|c|}{530.59} \\
\hline West & & & & \multicolumn{2}{|l|}{382} & \multicolumn{3}{|c|}{378.79} \\
\hline \multirow[t]{3}{*}{ Total } & & & & \multicolumn{2}{|l|}{1126} & \multicolumn{3}{|c|}{1126.00} \\
\hline & & & & \multicolumn{2}{|l|}{$\operatorname{chi2}(1)$} & \multicolumn{3}{|c|}{6.16} \\
\hline & & & & \multicolumn{2}{|l|}{ Pr>chi2 } & \multicolumn{3}{|c|}{0.046} \\
\hline \multicolumn{3}{|c|}{ Level of education } & & \multicolumn{2}{|l|}{$\begin{array}{c}\text { Events } \\
\text { observed }\end{array}$} & \multicolumn{3}{|c|}{$\begin{array}{c}\text { Events } \\
\text { Expected }\end{array}$} \\
\hline Level1 & & & & \multicolumn{2}{|l|}{82} & \multicolumn{3}{|c|}{107.24} \\
\hline Level2 & & & & \multicolumn{2}{|l|}{569} & \multicolumn{3}{|c|}{603.80} \\
\hline Level3 & & & & \multicolumn{2}{|l|}{187} & \multicolumn{3}{|c|}{187.75} \\
\hline Level4 & & & & \multicolumn{2}{|l|}{143} & \multicolumn{3}{|c|}{116.35} \\
\hline Level5 & & & & \multicolumn{2}{|l|}{126} & & 91.80 & \\
\hline Total & & & & 1107 & & & 1107.00 & \\
\hline & & & & $\operatorname{chi2(1)}$ & & & 36.34 & \\
\hline & & & & Pr $>$ chi2 & & & 0.0000 & \\
\hline
\end{tabular}

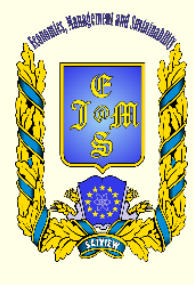

(c) 2016-2020, Economics, Management and Sustainability. All rights reserved.

This open access article is distributed under a Creative Commons Attribution (CC-BY) 4.0 license.

You are free to:

Share - copy and redistribute the material in any medium or format Adapt - remix, transform, and build upon the material for any purpose, even commercially.

The licensor cannot revoke these freedoms as long as you follow the license terms.

Under the following terms:

Attribution - You must give appropriate credit, provide a link to the license, and indicate if changes were made.

You may do so in any reasonable manner, but not in any way that suggests the licensor endorses you or your use.

No additional restrictions

You may not apply legal terms or technological measures that legally restrict others from doing anything the license permits.

Economics, Management and Sustainability (ISSN: 2520-6303) is published by Scientific Publishing House "CSR",

Poland, EU and Scientific Publishing House "SciView", Poland

Publishing with JEMS ensures:

- Immediate, universal access to your article on publication

- High visibility and discoverability via the JEMS website

- Rapid publication

- Guaranteed legacy preservation of your article

- Discounts and waivers for authors in developing regions

Submit your manuscript to a JEMS at http://jems.sciview.net or submit.jems@sciview.net 